PROCEEDINGS OF THE WORLD CONFERENCE ON OZONE THERAPY IN MEDICINE, DENTISTRY AND VETERINARY. ANCONA (ITALY). SEPTEMBER 22nd - 23rd - 24th, 2017

\title{
Oxidative stress, aesthetics and ozone therapy: the role of biological markers [abstract]
}

\author{
Eugenio Luigi lorio
}

International Observatory of Oxidative Stress, Salerno, Italy.

\section{ABSTRACT}

\section{OPEN ACCESS}

\section{Citation}

Iorio EL. Oxidative stress, aesthetics and ozone therapy: the role of biological markers [abstract]. Proceedings of The World Conference on Ozone Therapy in Medicine, Dentistry and Veterinary. Ancona (Italy). September 22nd - 23rd - 24th , 2017. J Ozone Ther. 2019;3(4):43-44. doi: 10.7203/jo3t.3.4.2019.15525

\section{Academic Editor \\ Jose Baeza-Noci, \\ School of Medicine, Valencia \\ University, SPAIN}

\section{Editor}

World Federation of Ozone Therapy, Bolgna, ITALY

\section{Received}

June 17, 2019

\section{Accepted}

December 08, 2019

Published

December 30, 2019

\section{Intellectual Property}

Eugenio Luigi lorio.

This is an open access article distributed under the terms of the Creative Commons Attribution License (CC BY 4.0), which permits unrestricted use, distribution, and reproduction in any medium, provided the original author and source are credited.

\section{Author Information}

eugenioluigi.iorio@gmail.com
The redox system, that includes both reactive oxidising species (ROS) and antioxidants (AOs), play an unique role in the maintenance and in the promotion of wellness of all tissues and organs including skin and subcutaneous being related through the so called "eu-oxidative stress" to all basic processes of life i. e. the flow energy and information [1]. Any disturbance of such system can lead to the "oxidative di-stress syndrome", that is believed co-responsible not only of early aging but also of at least one hundred diseases including cardiovascular diseases, neurodegenerative disorders and cancer [2, 3].

Oxidative di-stress is also involved in the pathophysiology of aesthetic as well as dermatological diseases like photo-aging, wrinkles, cellulite, and delayed wound healing [4]. Unfortunately oxidative stress does not show any specific clinical picture but can be diagnosed only by means of specific biochemical tests on biological fluids [5]. This approach led to the development of new branch of applied biochemistry and molecular diagnostics called Redoxomics [6].

Redoxomics is a novel branch of "applied biochemistry" and "molecular diagnostics" having the following aims:

I. to analyse the structure, the physiological role and the distribution of OCS and antioxidant systems in a living organism;

II. to identify the reciprocal interactions of oxidant and antioxidant systems in the general flow of information - in a biological system (cell, tissue, organ, apparatus, system, whole organism) in a defined step of its development, in basic conditions as well as after potentially stressful stimuli;

III. to evaluate the implications of these findings by the view-point of epidemiology, patho-physiology, clinics, pharmacology and so on [6].

On the basis of a Redoxomics profile the clinicians as well as the surgeons can identify early this new syndrome and to fight it by using not only more properly the conventional strategies but also new approach based on lifestyle changes [3], physiological redox modulators [7], biocompatible biomaterials (e. g. threads) [8, 9], gases (e. g. oxygen infusion/propulsion, carboxy therapy, ozone therapy) [10] which action is aimed to modulate the redox system function. Indeed the maintenance of a optimal oxidative balance is becoming one of the true pre-requisite "to be beautiful on the outside and on the inside". 


\section{References}

1. Iorio EL. Free radicals, antioxidants and oxidative stress in aesthetic medicine and dermatology. Eur J Aesthet Med Dermatol. 2016;6(1):9-47.

2. Dalle-Donne I, Rossi R, Colombo R, Giustarini D, Milzani A. Biomarkers of oxidative damage in human disease. Clinical Chemistry. 2006;52(4):601-623.

3. Iorio EL. Lifestyle-related diseases and oxidative stress. Official Journal of Japan Society of Ningen Dock. 2009;24(2):612.

4. Iorio EL. Oxidative stress evaluation and hustological analysis in the assessment of cellulite: lights and shadows towards a multidisciplinary apporach. Eur J Aesthet Med Dermatol. 2015;3(2):46-53.

5. Iorio EL, Balestrieri ML. [The oxidative stress] In: Burlina A. Trattato Italiano di Medicina di Laboratorio. Ed. Balestrieri C Piccini, Padua-Italy; 2009. p. 533-549.

6. Iorio EL, Marin MG. Redoxomics. An integrated and practical approach to genomics, metabolomics and lipidomics to manage oxidative stress. Gen-T. 2008;2:67.

7. Cornelli U, lorio EL. Antiossidanti. Aspetti terapeutici e diagnostici. Guna Ed, Milano; 2007.

8. Atiyeh BS, Dibo SA, Costagliola M, Hayek SN. Barbed sutures "lunch time" lifting: evidence-based efficacy. J Cosmet Dermatol. 2010;9(2):132-1341.

9. Suh DH, Jang HW, Lee SJ, Lee WS, Ryu HJ. Outcomes of polydioxanone knotless thread lifting for facial rejuvenation. Dermatol Surg. 2015;41(6):720-772.

10. Zanardi I, Borrelli E, Valacchi G, Travagli V, Bocci V. Ozone: a multifaceted molecule with unexpected therapeutic activity. Curr Med Chem. 2016;23(4):304-314. 